\title{
三川合流部における洪水流と河床変動解析 一格子非直交成分の運動量フラックスの導入 NUMERICAL ANALYSIS OF FLOOD FLOWS AND BED VARIATIONS AT THREE RIVER CONFLUENCES - INTRODUCING MOMENTUM FLUX FROM NON-ORTHOGONAL DIRECTION OF GRID LINE
}

\author{
竹村吉晴 1 福岡捷二 2 ・杉村貴志 3 \\ Yoshiharu TAKEMURA, Shoji FUKUOKA and Takashi SUGIMURA \\ 1正会員 博(工) 中央大学研究開発機構助教（广112-8551 東京都文京区春日1-13-27） \\ 2フェロー 工博 Ph.D. 中央大学研究開発機構教授（同上）

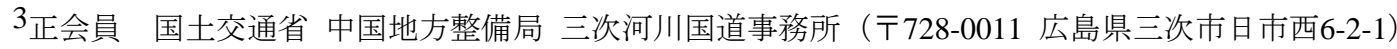

\begin{abstract}
In this study, the quasi-3D model composed of depth-integral vortex equation and shallow water equations was extended on the basis of finite volume method employing non-orthogonal grids for properly evaluating complex boundary of the confluences. And, we developed the flux integral method considering non-orthogonal direction of grid line based on the CIP-CSL scheme for evaluating the convection terms more accurately also in the complex flow field of the confluence.

The extended quasi-3D model was applied to recent large floods at the Go River confluences to investigate the flood flow and bed variation during the flood events. From the calculation results, we clarified that separation zones formed at the confluences have pronounced effects on the three dimensional flow structure and bed variations for the downstream channel.
\end{abstract}

Key Words : River confluence, Flood flow, Bed variation, Flux integral, CIP_CSL

\section{1. 序論}

図-1は対象とした江の川三川合流部の平面形状を示寸. 江の川では，三次盆地において，ほぼ同規模の流域面積 を持つ馬洗川，西城川が短い区間で合流している．この ような同規模の河川が複数合流する河川合流部では, 複 雑な河道線形を持ち, 各河川からの運動量及びその比に よって, 三次元的に複雑な流体混合が生じる. それに よってもたらされる洪水流と河床変動の把握は河川管理 上の重要な課題の一つである.

近年では, 計算機能力の向上により, 三次元乱流モデ ルを用いた河川合流部の三次元的な流れ構造の検討が行 われるようになってきている1). しかし，河川合流部の 流れと河床変動は，時空間的に広い範囲の流れに影響を 与えることから，より実用的な数值解析モデルが必要と されている. 内田らは, 浅水流方程式と水深積分された 渦度方程式加ら構成される準三次元洪水流解析法（底面 流速解法）を提案している2゙，底面流速解析法は，鉛直 方向に計算格子を設けることなく, 水平方向流速の鉛直
水位·流量観測所位置

*() 内は距離標之流域面積

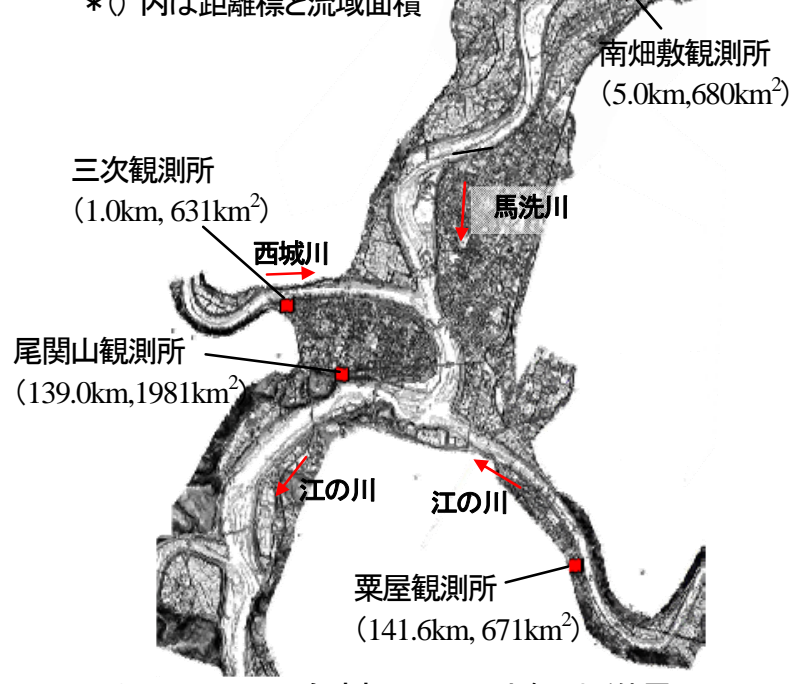

図-1＼cjkstart江の川三川合流部の平面形と観測所位置

分布を解析できることから，三次元解析に比べ三次元的 な流れ場を効率的に計算することが可能である. 一方で, 浅水流方程式と水深積分渦度方程式を連立して解くこと から, 水深平均流速場の解析精度が水深平均渦度の輸送 


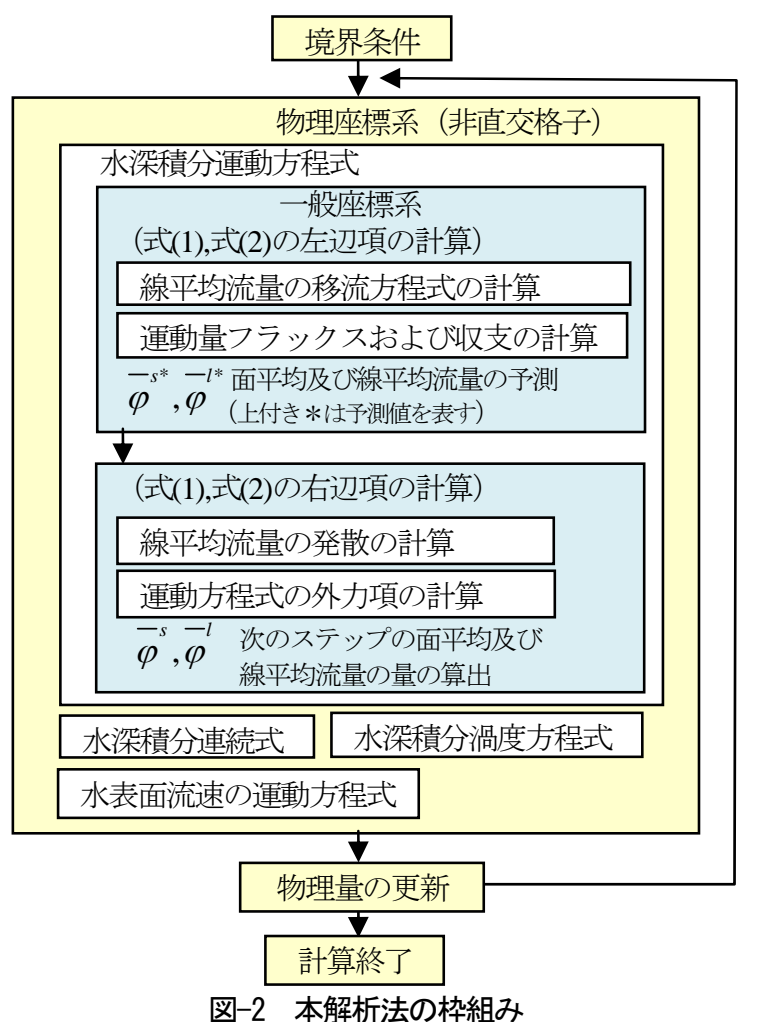

や回転・伸縮に直接影響を与えることになる．このため， 浅水流方程式における移流項の扱いが，河川合流部にお ける三次元的な流れ場や河床変動の解析結果を左右寸る ことになる.

これまで, 移流項の高精度化については多くの手法が 提案されているが，河川流のような多次元の問題に特有 の流れ方向と計算格子方向の相違による数值誤差3,44につつ いては議論されることが少ない. しかし，図-1に示した 江の川三川合流部のように，同規模の河川が複数合流す る場合には，この影響を無視し得ないものと考えられる。

本研究では，格子非直交成分（計算格子の方向と異な る方向成分）を含めた運動量フラックスの計算法を開発 し，これを底面流速解法に導入することで，江の川三川 河川合流部における数值解析モデルを構築する. さらに, 開発したモデルを近年の主要洪水に適用することで，解 析法の適用性及び江の川三川合流部における洪水流と河 床変動について検討を行う。

\section{2. 解析方法}

\section{（1）本解析法の枠組み}

図-2に本解析法の枠組みを示す，本研究では，河川合 流部のような複雑な境界形状を適切に評価するため, 内 田らにより提案された底面流速解法を有限体積法に基づ き非直交格子上で離散化している. 本解析法では, 保存 型CIP法(CIP_CSL法) ${ }^{5}$ に基づき，格子非直交成分を含め た運動量フラックスの計算法が構築されることから（詳 細は2.(2)で説明する），式(1), (2)の計算格子において面

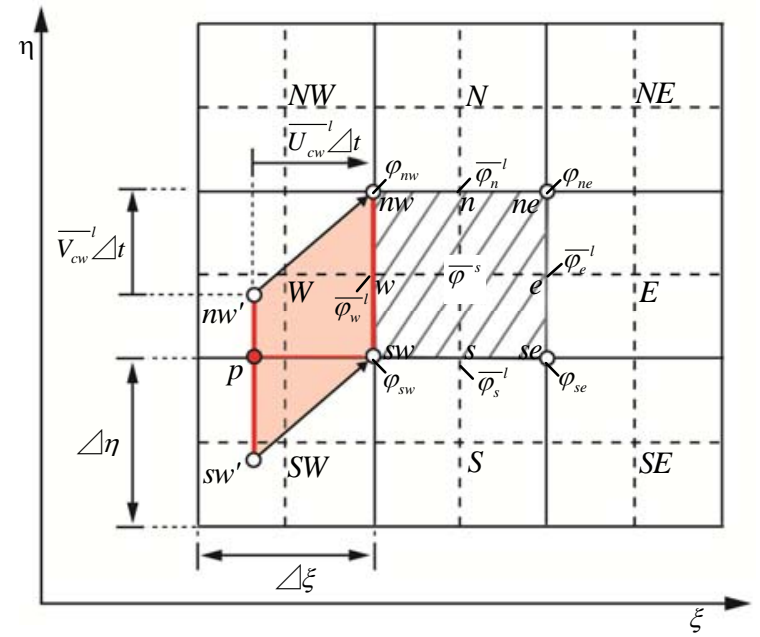

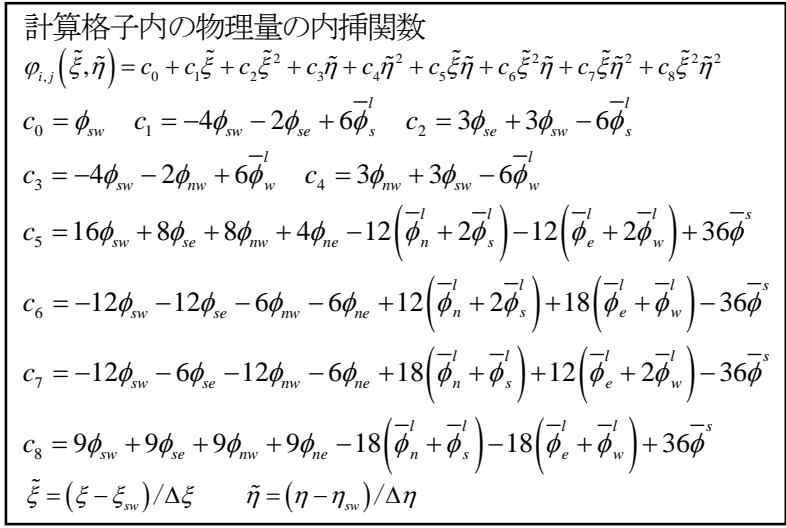

図-3 計算格子上の変数の配置と内挿関数

積分平均された単位幅流量(面平均流量)と計算格子境界 面で線積分平均された単位幅流量(線平均流量)に関する 運動方程式が解かれる。

$$
\begin{aligned}
& \frac{\partial \bar{\varphi}^{s}}{\partial t}+\frac{1}{S}\left(\text { Flux }_{e}-\text { Flux }_{w}+\text { Flux }_{n}-\text { Flux }_{s}\right)=\bar{D}^{s} \\
& \frac{\partial \bar{\varphi}^{l}}{\partial t}+\bar{U}^{l} \frac{\partial \bar{\varphi}^{l}}{\partial x}+\bar{V}^{l} \frac{\partial \bar{\varphi}^{l}}{\partial y}=-\bar{\varphi}^{l}\left(\frac{\partial \bar{U}^{l}}{\partial x}+\frac{\partial \bar{V}^{l}}{\partial y}\right)+\bar{D}^{l}
\end{aligned}
$$

ここに, $\varphi(=U h, V h): x, y$ 方向の水深積分運動量, $U, V: x, y$ 方向の水深平均流速, $h$ : 水深, $D$ : 水深積分運動方程式の 移流項以外の項, Flux $x_{e, w, n, s}$ : 図-3に示寸計算格子境界面e, $w, n, s$ からの運動量フラックス, $S:$ 計算格子の面積であ る. なお，上付き - $s,-l$ は計算格子における面積分平 均および計算格子境界面における線積分平均をそれぞれ 表す. 面平均流量と線平均流量の計算は，2つの段階に 分離し行われる. すなわち, はじめに式(1), 式(2)の左 辺項加面平均流量と線平均流量の予測值を計算し, そ の後, 式(1), 式(2)に右辺項（水面勾配項, 底面せん断 応力項, 水平方向せん断応力項, 樹木群による抵抗項) を加えることで，次のステップの面平均流量と線平均流 量を算出する. 底面せん断応力は粗度係数, 樹木群の抵 抗は樹木群透過係数(6)を用いてそれぞれ評価する. 水平 方向のせん断応力には, 乱流混合及び水深平均流速から の偏差成分による運動量交換を考慮している. また，非 


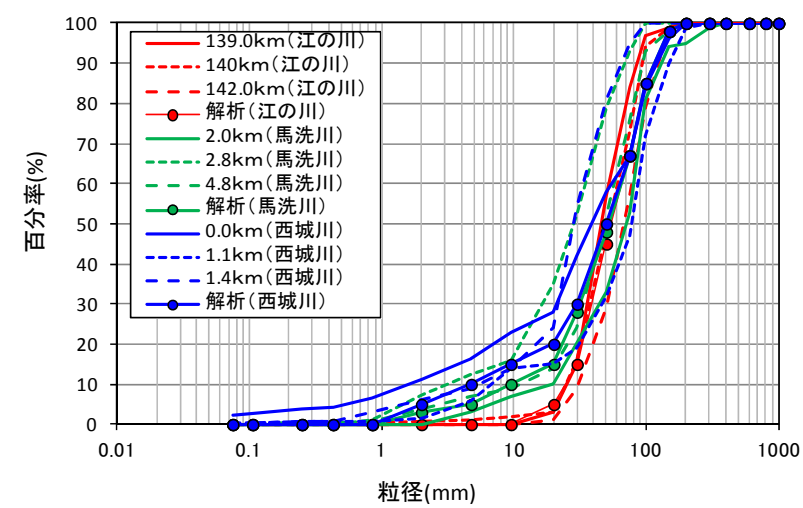

図-4＼cjkstart対象区間における河床粒度分布

直交格子では計算格子が歪を持つため, 計算格子内の物 理量の内挿関数を定義することが困難であることから， 式(1), 式(2)の左辺項の計算は一般座標系において行う.

\section{（2）水深積分運動方程式の移流項の計算方法}

一般に, CIP_CSL法の多次元化は, 計算格子内の物理 量を一次元関数から内挿し, 方向毎に移流項の計算が行 われる (次元分割法) ${ }^{5}$. 一一方, 内挿関数に多次元の関 数を用いた場合には, 次元分割法に比べ計算の精度, 安 定性ともに向上することが知られている7．しかし， CIP_CSL法では，セミラグランジュ的に物理量の移流が 計算されるため, 面平均物理量の移流計算には, 計算格

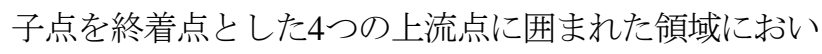
て, 内挿関数の厳密な積分が要求され, 計算が非常に煩 雑となる. それに対し, 本研究では, 各計算格子境界面 からの平均的な運動量フラックスを計算し, 面平均流量 を運動量フラックスの収支から求めることで，より実用 的な方法を提案する.

図-3に計算格子内の変数の配置および内挿関数を示寸. 内挿関数には二次元の二次多項式を用いた. ここで, 各 計算格子点上の単位幅流量 $\varphi_{\text {sw, nw se ne }}$ は計算の効率化を図 るため, 周囲の計算格子境界面における線平均流量から 線形補間することとした. 内装関数の定数 $C_{0 \sim 8}$ は, 各 計算格子における格子点上の単位幅流量, 格子境界面に おける線平均流量, 面平均流量を拘束条件として求めら れる. 以下に図-3に示寸計算格子境界面wを例に, 線平 均流量および運動量フラックスの計算手順を説明する. まず，一般座標系において，計算格子境界面 $w$ の線平均 された水深平均流速ベクトルの $\xi$ 方向反変成分と $\eta$ 方向反 変成分と計算の時間刻み幅 $\Delta t$ 積から上流点 $n w^{\prime}, s w^{\prime}$ を 定める. $\Delta t$ 後の格子境界面 $w$ の線平均流量は, 計算格 子WおよびSWでそれぞれ定義される内挿関数を $n w^{\prime} \sim p$, $p \sim s w^{\prime}$ の範囲でそれぞれ線積分し，これらの和から計算 される，境界面Wの運動量フラックスは，計算格子Wの $n w ， n w^{\prime}, p, s w に$ にまれた領域，計算格子SWの $s w, p$, $s W^{\prime}$ に囲まれた領域で内挿関数をそれぞれ面積分し，こ れらの和として計算される. 同様の手順により各計算格 子境界面の線平均流量と運動量フラックスが計算される.

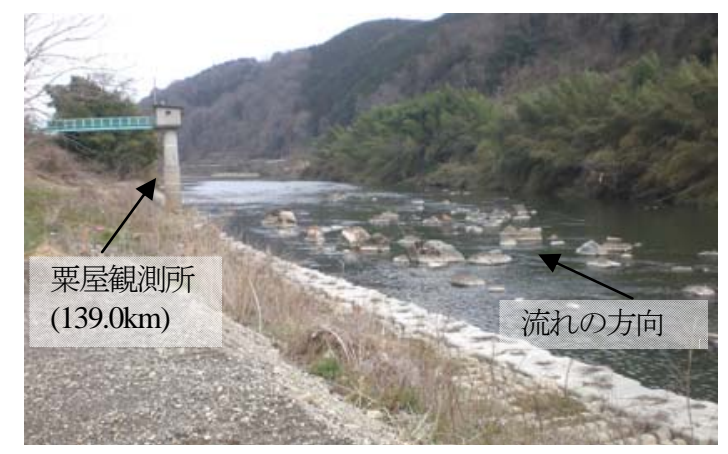

図-5 江の川粟屋観測所 (141. 6km) 付近の河床の様子 (平成23年4月撮影)

\section{3. 江の川三川合流部への適用と解析結果の考察}

\section{（1）対象区間及び洪水概要}

図-1に示した江の川三川合流部では，既に福岡，西村 $ら^{8}$ によって非定常準三次元解析モデルが構築されてい るが，解析はS-N座標系に基づくことから，二次流形成 に重要となる河道線形の解析一の取り込みや移流項の扱 いに限界があった。

対象区間では，平成10年10月，平成11年6月に，基準 点の尾関山観測所地点において, 計画流量 $7600 \mathrm{~m}^{3} / \mathrm{s}$ に対 しそれぞれ $4700 \mathrm{~m}^{3} / \mathrm{s}, 4800 \mathrm{~m}^{3} / \mathrm{s}$ 程度の流量が観測される 大洪水が発生した. 本研究では, 2. において構築した 解析モデルを平成10年10月，平成11年6月洪水に適用す ることで，解析モデルの適用性および三川合流部の洪水 流と河床変動特性について検討する.

\section{（2）解析条件}

上流端の境界条件には，図-1に示した江の川の粟屋観 測所(141.6km), 馬洗川の南畑敷観測所(5.0km), 西城川 の三次観測所 $(1.0 \mathrm{~km})$ における観測水位の時系列データ をそれぞれ与え，下流端の境界条件は，江の川の尾関山 観測所 $(139.0 \mathrm{~km})$ における観測水位の時系列データとし た. 河床抵抗は粗度係数で評価し, 図-4に示寸ように各 河川で河床材料分布が大きく違わないことから, 全ての 河川で低水路粗度係数を 0.03 で与えた. 高水敷粗度係数 は，江の川と西城川では0.04，馬洗川では他の河川に比 べ植生の繁茂が顕著であるため 0.045 と高めに設定した。 また，樹木群の抵抗は樹木群透過係数 6 で評価し，K=30 〜50の範囲で与えている. なお，粟屋観測所(141.6km) 付近では, 図-5に示すように河床に岩が露出しているこ とから低水路粗度係数を局所的に高く $(n=0.042)$ してい る. 河床変動解析は混合粒径で行い, 図-4のプロットで 示寸粒度分布を各河川において与えている. 各粒径の流 砂量は, 芦田・道上9による粒径別の平衡流砂量式から 計算し, 各粒径の限界掃流力は修正Egiazaroff式 よりそ れぞれ与える. また, 各粒径の存在割合の計算には平野 


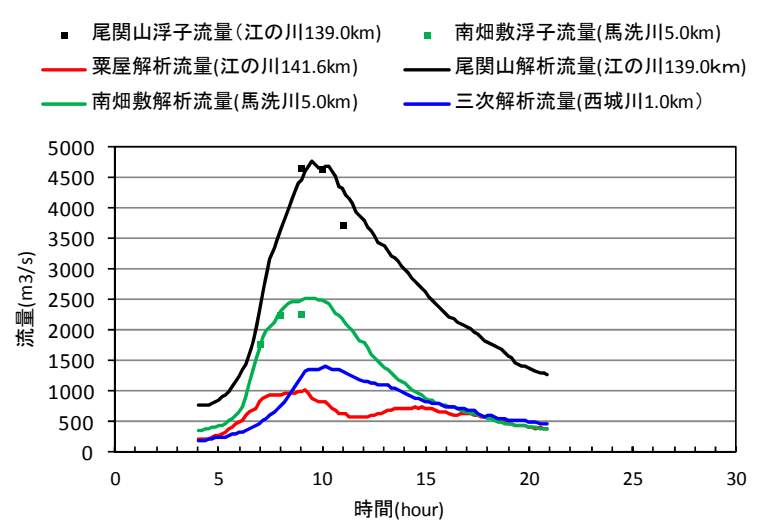

(a) 平成10年10月洪水

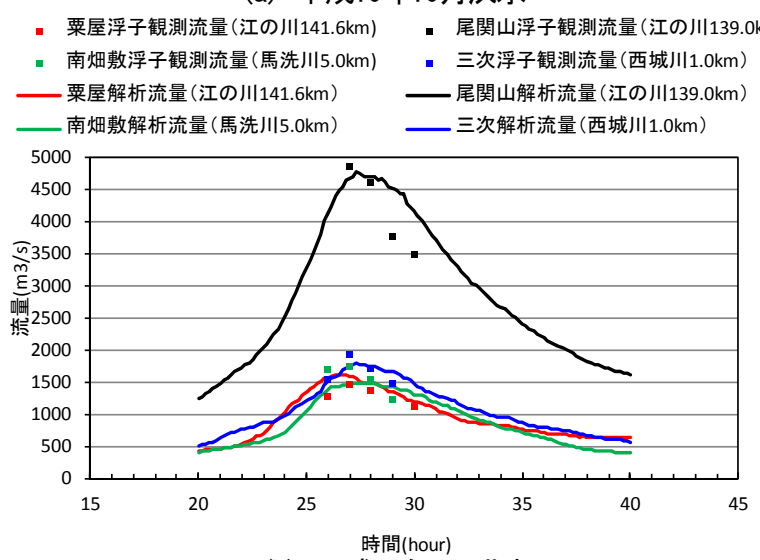

(b) 平成11年6月洪水

図-6 江の川平成10年10月，平成11年6月洪水の観 測流量と解析流量の比較

の交換層 ${ }^{10)}$ モデルを採用し，交換層厚は最大粒径の2 倍程度として $15 \mathrm{~cm}$ とした. 解析に用いる初期河床高は, 平成9年に測られた $200 \mathrm{~m}$ 間隔の定期横断測量結果を基に, 平成10年に撮影された平水時の航空写真を参考として合 流点の砂州形状等を出来る限り再現寸るように作成した.

\section{（3）解析結果と考察}

図-6 (a)，(b) は，平成10年10月，平成11年6月洪水時の 各観測所における観測流量（プロット） と解析流量（実 線）の比較を示寸. 平成10年10月洪水は, 馬洗川からの 流量が卓越した洪水であったのに対し，平成11年6月洪 水は三川ともにほぼ同程度の流量が観測されている. 解 析流量は, 両洪水ともに, 減水期において尾関山観測所 における解析流量が観測流量より大きい傾向にあるが, 他の観測所において観測流量をほぼ説明できていること から，概初妥当な結果と言える．図一-7は，平成10年10月， 平成11年6月洪水時の痕跡水位と解析最大水位の縦断形 の比較を示寸. 解析最大水位は，支川流入の影響が顕著 に表れる合流区間直上流での痕跡水位の縦断形およびそ の高さを良好に説明している．一方で，馬洗川の $2.0 \mathrm{~km}$ より上流区間では, 痕跡水位と解析最大水位に大きな違 いが生じている，痕跡水位にもある程度の誤差が含まれ ることが予想されるが，本研究では，樹高の比較的低い 植生の抵抗は, 粗度係数より評価することとし, 高水敷

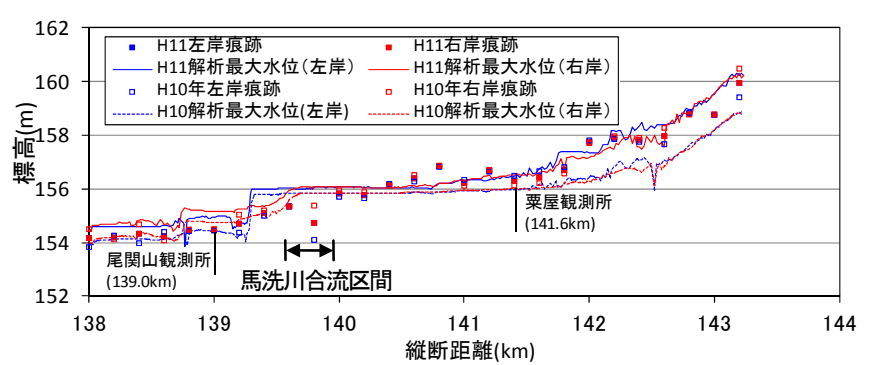

(a) 江の川

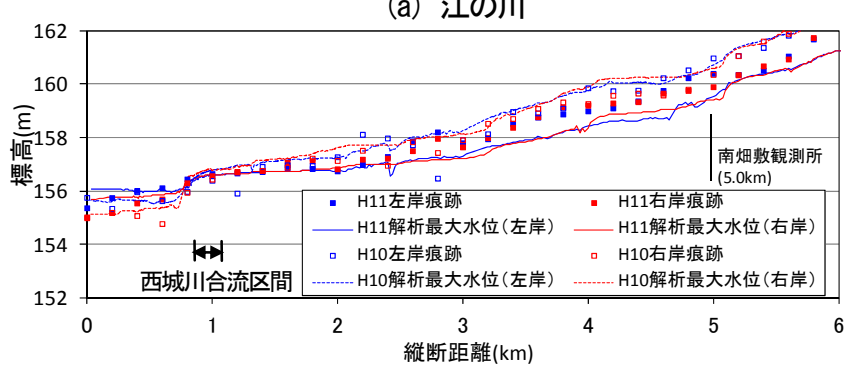

(b) 馬洗川

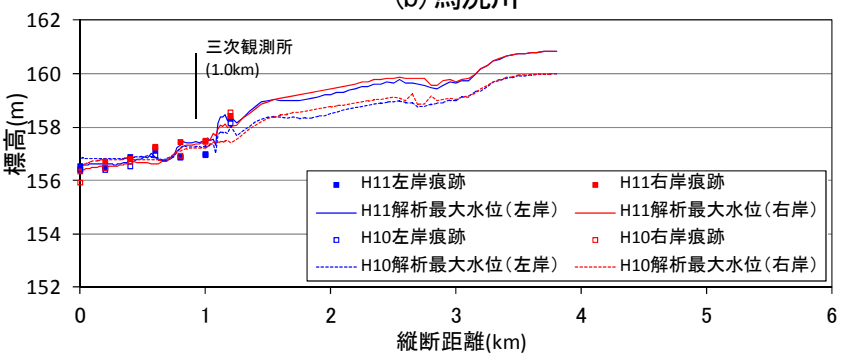

(c) 西城川

図-7 江の川平成10年10月，平成11年6月洪水の痕跡水位と 解析最大水位の継断形の比較

に高い粗度 $(n=0.045)$ を律に与えたことが主な原因とし て考えられる。

次に, 実測データと数值解析の結果から, 江の川三川 合流部における洪水流と河床変動について検討寸る. 図 -8 (a)，(b) は，平成10年10月洪水ピーク時における主流 方向の水深積分渦度の空間分布を 10 分平均值と瞬間値に 分けて示寸. 水深平均渦度の空間分布は各瞬間で大きく 変化しており, 瞬間值は10分平均值との違いが顕著な瞬 間を描いたものである.コンターの色が赤であれば主流 に対して右回り, 青であれば左回りの水深積分渦度が形 成されていることを表す. 図-8 (a), (b)の黒点線は, 10 分平均の流れ場から確認された剥離境界線を示している. 三川合流部では，剥離域から供給される渦により，その 下流河道で流れ場に時間的な変動が見られた. そのため, 図-8 (a)，(b)の比較から分かるように，10分平均值之瞬 間值では，流れの三次元構造が大きく異なる．特に，馬 洗川と西城川の合流点および江の川 $139.4 \mathrm{~km}$ 下流の水衝 部に形成された剥離域の下流区間」において，その差が 顕著となっている，また，平成10年10月洪水では，馬洗 川からの流量が卓越していたことから, 西城川合流点下 流の河道線形や江の川からの運動量供給によって生成さ れた主流に対して左回りの水深積分渦度が139.6km付近 まで輸送されていることが分かる.

図-9(a)，(b) は，江の川平成10年10月，平成11年6月 


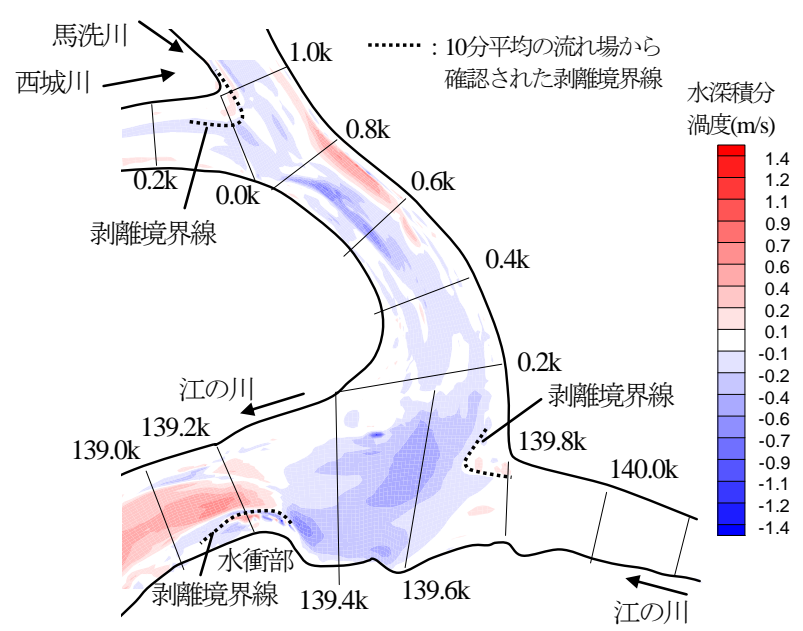

(a) 10 分平均値

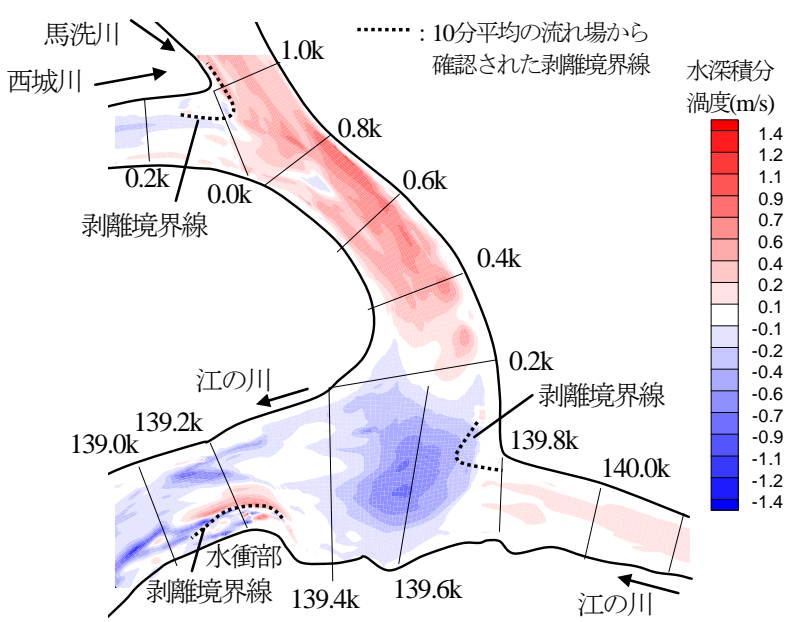

(b) 瞬間値

図-8＼cjkstart江の川平成10年10月洪水ピークにおける水深積分渦度の空間分布

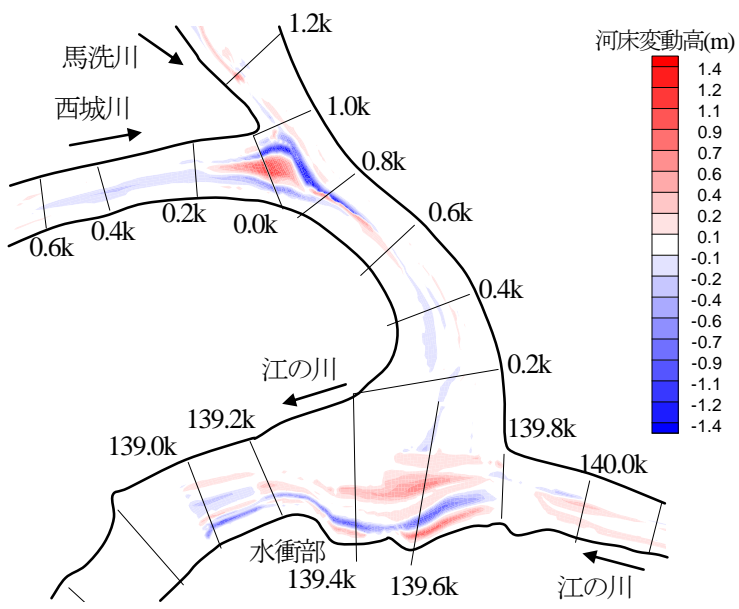

(a) 実測の河床変動高コンター

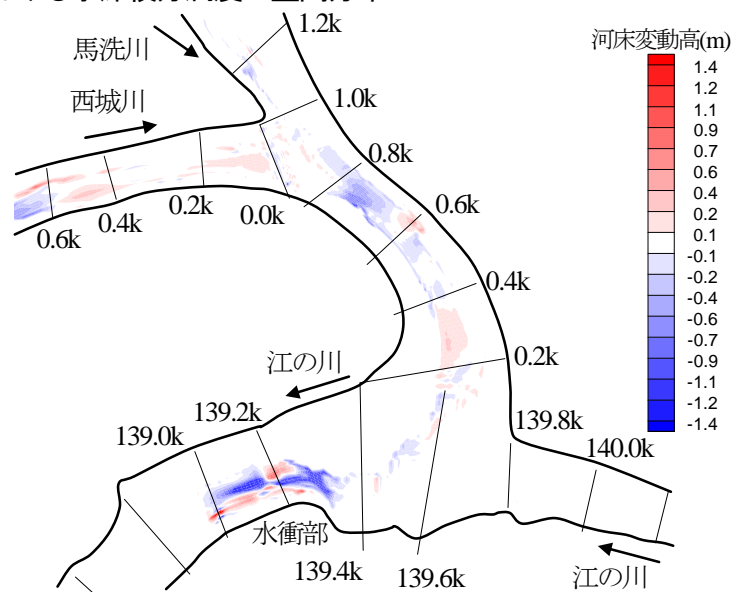

(b) 解析の河床変動高コンター

図-9 江の川平成10年10月，平成11年6月洪水前後での実測と解析河床変動高コンターの比較

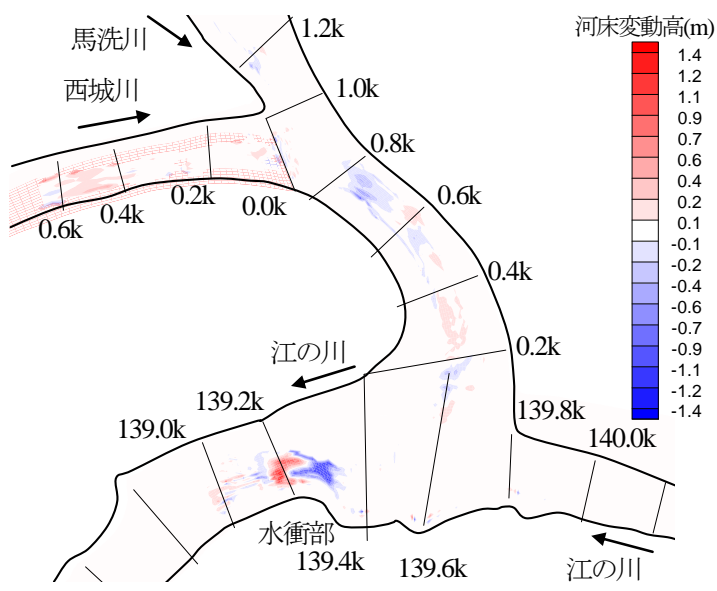

図-10 江の川平成10年10月，平成11年6月洪水前後での 解析河床変動高コンター（格子非直交成分の運動量フ ラックスを考慮しない場合）

洪水前後での実測と解析の河床変動高コンターの比較で ある．なお，河床変動高コンターは，解析において河床 変動解析を行った江の川の尾関山観測所 $(139.0 \mathrm{~km})$ まで の区間を示している．また，江の川139.4km下流の水衝 部においては，岩が露出していることから，経年的な横 断測量結果の比較から, 河床高の変化がほとんど見られ
ない範囲は岩が露出しているものとして, 河床変動計算 において河床低下が生じないようにしている. 図-9(a) に示寸実測值では，馬洗川と西城川合流点における土砂 の堆積および江の川の139.8kmから下流の外岸側での河 床洗掘が特徵的である. 図-9(b) に示寸解析值は, 馬洗 川と西城川合流点の砂州上で堆積傾向を示寸ものの堆積 量は実測に比べ小さい，また，解析值は江の川 $139.4 \mathrm{~km}$ 下流の水衝部における洗掘傾向を捉えているものの，河 床洗掘は実測值に比心横断方向に広く, 縦断方向に短い 範囲で起きており，洗掘量は過大になっている.

次に，格子非直交成分の運動量フラックス（以下，格 子非直交成分と省略寸る）考慮前後での解析結果の比較 から本解析法の有効性について検討寸る. 図-10は本解 析において格子非直交成分を考慮しない場合の解析河床 変動コンターを示寸. 図-10に比べ, 図-9(b) の格子非直 交成分を考慮した場合では水衝部下流139.0～139.2km区 間で河床低下傾向にあり, 図-9(a)の実測值の傾向に近 づいている. 図-11は, 河床変動が最も活発であった平 成10年10月洪水ピーク時の水表面及び底面近傍における 水粒子の軌跡を格子非直交成分考慮前後で比較している. 水表面近傍の水粒子の軌跡は, 寿橋（江の川 $140 \mathrm{~km}$ 付近） 


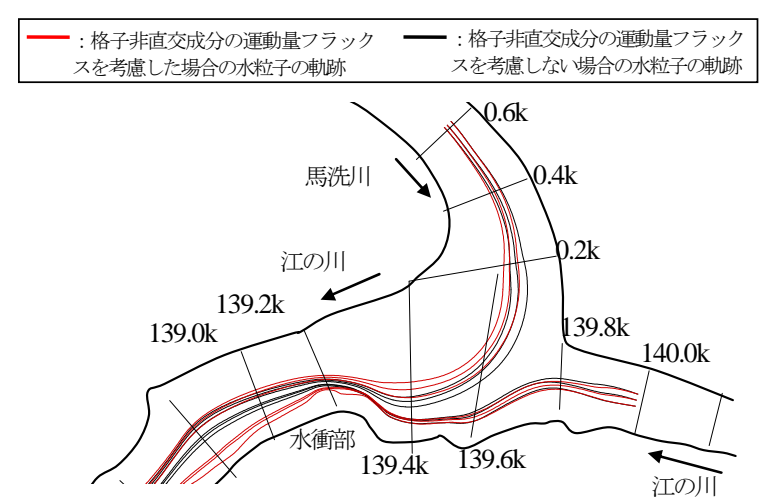

（a）水表面近傍における水粒子の軌跡

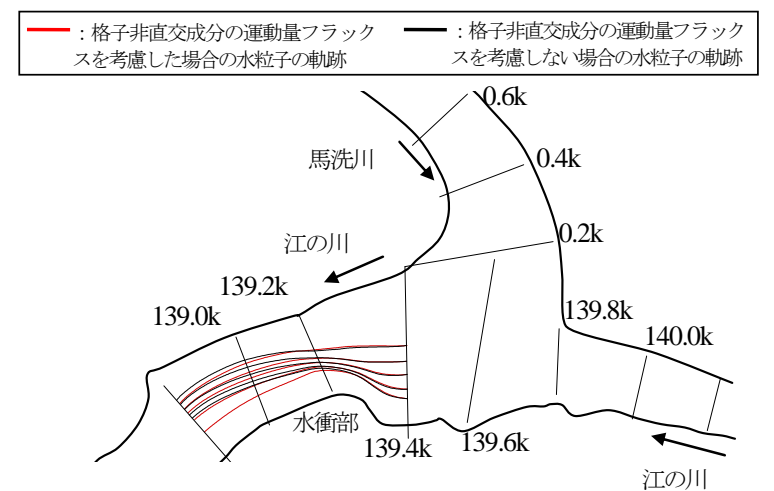

（b）底面近傍における水粒子の軌跡

図-11 格子非直交成分の運動量フラックス考慮前後での 平成10年10月洪水ピーク時の水表面及び底面近傍におけ る水粒子の軌跡の比較

及び巴橋（馬洗川0.6km付近）から浮子を投下した場合 を想定し，底面近傍の水粒子の軌跡は江の川 $139.4 \mathrm{~km}$ 流の水衝部付近に着目し，それぞれ10分平均の水表面流 速及び底面流速の解析值から求めている. 図-11(a)の水 表面における水粒子の軌跡は，江の川と馬洗川の合流点 および水衝部下流区間において，格子非直交成分考慮前 後での違いが大きくなっている. 図-11 (b) の底面近傍に おける水粒子の軌跡は，格子非直交成分を考慮した場合

(赤線) では，考慮しない場合（黒線）に比べ水衝部下 流区間で水粒子の軌跡が全体的に左岸側に寄っており， このことが図-9 (b) と図-10での河床変動コンターの違い を引き起こした主要因と考えられる.

本研究では，実測や格子非直交成分の運動量フラック 又考慮前後での解析結果の比較から, 本解析法の有効性 について検討を行った. しかし，検証データの不足から 未だ十分な検討に至っていない. 本解析では, 図-11 (a) に示したように比較的観測が容易な水表面における水粒 子の軌跡などを求めることが可能である．現在，江の川 三川合流部では，詳細な縦横断水位観測および航空写真 やGPSフロート等による洪水流水表面流速や軌跡の観測 準備がなされている. 今後, これらの観測結果や洪水前 後の河床変動の観測結果を用いて，さらに，本解析法の 有効性について検証を進める.

\section{4. 結論}

（1）格子非直交成分（計算格子の方向と異なる方向成 分）を含めた運動量フラックスの計算法を開発し, 水深積分された渦度方程式と浅水流方程式から構成 される準三次元洪水流解析法 (底面流速解法) に導 入することで，同規模河川が複数合流する河川合流 部における洪水流と河床変動解析モデルを構築した.

（2）構築したモデルを江の川三川合流部における近年 の主要洪水である平成10年10月，平成11年6月洪水 に適用し，解析モデルの適用性および三川合流部に おける洪水流と河床変動について検討した．解析結 果の分析から江の川三川合流部では，合流部や水衝 部に形成される剥離域の存在がその下流河道の三次 元的な流れ構造に大きく影響することを示した.

\section{参考文献}

1) Miyawaki, S., Constantinescu, G., Rhoads, B., Sukhodolov, A.:Changes in three-dimensional flow structure at a river confluence with changes in momentum ratio, Proc. River Flow, Braunschweig, Germany, 2010.

2) 内田龍彦，福岡捷二 : 底面流速解法による連続する水没水制 群を有する流れと河床変動の解析, 土木学会論文集B1, Vol. 67, No. 1, 16-29, 2011.

3) Rhie, C. M. and Chow, W. L. : Numerical study of the turbulent flow past an airfoil with trailing edge separation, AIAA Journal, Vol. 21, No.11, pp. 1525-1532, 1983.

4) Leonard B. P., MacVean M. K., and Lock A. P. :The flux-integral method for multidimensional convection and diffusion, NASA Tech. Memo., pp. 333-342, 1994.

5) Nakamura, T., Tanaka, R., Yabe, T. and Takizawa, K.: Exactly Conservative Semi-Lagrangian Scheme for Multi-dimensional Hyperbolic Equations with Directional Splitting Technique, Journal of Computational Physics, Vol. 174, pp. 171-207, 2001.

6) 福岡捷二, 佐藤宏明, 藤澤寛, 大沼史佳 : 洪水流と河道の 樹木繁茂形態に基づく樹木群透過係数と粗度係数の算定法, 水工学論文集，Vol. 51，pp. 607-612， 2007.

7) 滝沢研二, 矢部 考: 保存型保証多次元セミラグランジュス キームの開発，第14回数值流体力学シンポジウム, pp.1-6, 2000.

8）福岡捷二，五十嵐崇博，西村達也，宮崎節夫 : 河川合流部の 洪水流と河床変動の非定常三次元解析，水工学論文集，第39 巻, pp. 435-440, 1995.

9) 芦田和男・道上正䂓 : 移動床流れの抵抗と掃流砂量に関寸る 基礎的研究，土木学会論文報告集，第206号，pp.59-69，1972。

10) 平野宗夫 : Armoringをともなう河床低下について, 土木学会 論文報告集，第195号，pp.55-65，1971.

（2012. 9. 30受付） 